\title{
FROM A PRIVATE COLLECTION TO A STATE MUSEUM: PAULS STRADIN̦Š MUSEUM OF THE HISTORY OF MEDICINE
}

\author{
Juris SAlaks ${ }^{1}$, Kaspars VANags ${ }^{2}$ \\ ${ }^{1}$ Institute of the History of Medicine, Rīga Stradiñš University, Rìga, Latvia \\ ${ }^{2}$ Pauls Stradiňs Museum of the History of Medicine, Rìga, Latvia
}

\begin{abstract}
In 2021, Pauls Stradiņš Museum of the History of Medicine in Rīga (Latvia) will celebrate 60 years since it acquired the status of a state museum. This article describes the history of its creation, the work of the museum from 1961 to 2019, its basic functions and structures, the consequences of ideological deviations, and outlines the vision for the future development of the museum.

On the one hand, the museum is based on the idea and collection of Doctor Pauls Stradiņš, an avid enthusiast, and his skill in keeping, supplementing, and improving his collection and legalising it as a state-run institution. However, no less important has been the attitude of the public and the authorities towards this institution, public support for P. Stradinšs idea. The relatively liberal attitude towards the initially private museum is explained by the fact that healthcare was declared one of the priorities of the Soviet Union, and the history of medicine was ideologically a relatively neutral field. In addition, the "national" moment was less emphasised in P. Stradiņš Museum in the context of Latvia, the museum mainly showed folk medicine, fighting against epidemics, medicine in cities but did not highlight medical achievements during the years of Latvia's independence.

The paradigm of the museum has changed today. Aspects of medicine, as in natural and technological sciences, which are within the competence of social history, anthropology and cultural theory have come to the fore. The experience of the global pandemic has brought conflict and tension into and around health in public opinion. This calls for a review of the six decades of exhibition traditions and the dynamics of the relationship with the museum's existing and potential audience, which has been cultivated for six decades.
\end{abstract}

Keywords: Latvia; museums; medical collections; research; history of medicine; art and medicine 


\section{THE CONCEPT OF CREATION OF THE MUSEUM}

The Museum of Medical History was not originally shaped according to a predesigned and carefully thought-out plan as a systematic presentation of medical history but emerged spontaneously over many decades as the embodiment of one person's interests and dedication. This person, Pauls Stradiñš (1896-1958), was at the same time a practicing doctor, medical scientist, organiser, educator, and a passionate collector of testimonies of the past (Fig. 1).

Professor Pauls Stradiņš was not a professional but rather an amateur medical historian, who, during his entire life, was interested in the past of his profession and in history in general. He understood the importance of visualisation; he tried to show young doctors and later also the general public the development of medicine in images (Fig. 2).

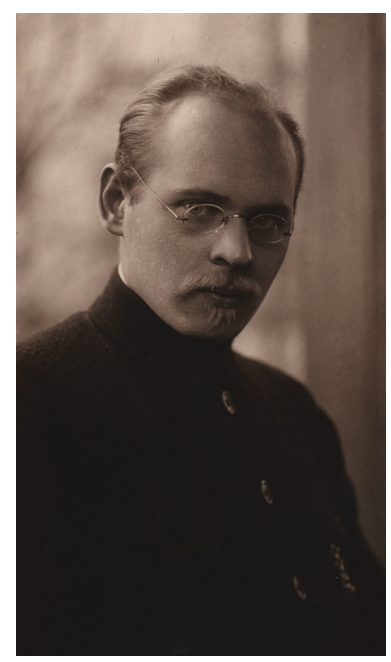

Figure 1. Pauls Stradinš (1896-1958). Early 1920-ties. (Pauls Stradinšs Museum of the History of Medicine).

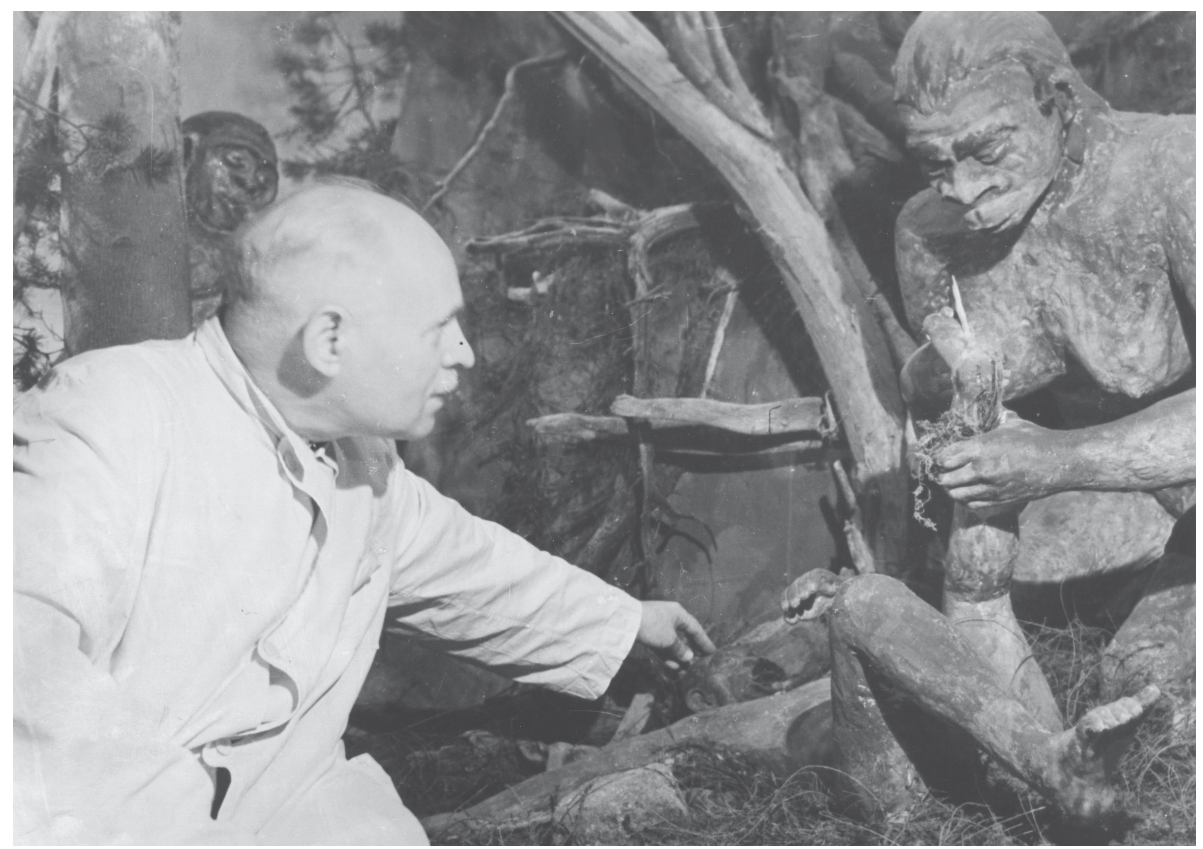

Figure 2. Professor Pauls Stradinš̌ creating diorama.1957. (Pauls Stradinš Museum of the History of Medicine). 
The creator of the museum specifically emphasised two moments - the progress of medicine and the doctors' love for people, their humanism and selfless service to the sick, suffering persons [1: 140].

The origins of the museum are linked to the training process of medical students. Pauls Stradiņš lectured on surgical pathology at Latvian University (single university, like Tartu University) at the Faculty of Medicine, and for this purpose started building a surgical pathology teaching museum, to some extent selecting the clinical museum of Professor Sergei Fyodorov (1869-1936), his teacher during his Petrograd period, and the collection of John Hunter (17281793) he saw in England as examples. Professor Pauls Stradiņš used to tell halfjokingly that the Museum of Medical History had started with a fight against smoking. Students stayed in the spacious lobby above the faculty's new auditoriums between lectures. They constantly extinguished cigarette butts on the panels along the walls. To eradicate this habit, Professor devised an unexpected technique - hanging portraits of distinguished medical practitioners of the past and engravings with stories about ancient medicine on the walls above the panels [2: 232-233].

This certainly had its effect, but, soon, a collection of pathoanatomical wet specimens of extirpated organs preserved in formalin, dummies with typical forms of malignancies, etc. started to grow. From the beginning, the "repository" of the Museum of Surgery was also supplemented with exhibits on medical history - engravings, scenes from medical practices of ancient times, caricatures, instruments. The collection was formed in a rather unsystematic manner, based on travel impressions or some random purchases. Such chaos, lack of systematicity also had a positive side - it allowed the collection to become encyclopaedic. Gradually, it turned into the idea of a universal museum of medicine that would not be confined to a certain era and country but would cover the history of civilisation in general.

In any case, the idea of the museum was promoted not only by didactic considerations - to visually demonstrate medical history to students - but also by the desire to popularise this field to the wider community, to speak about medicine and its history to everyone in an attractive and popular way.

The change of several powers in Latvia during World War II was reflected in the museum display. This was dictated by the political situation. "After the war, the department of Russian and Soviet medicine had to be expanded in the museum according to the task given by the ideologues of the Communist Party to show "the science of the motherland" and to highlight the priority of Russian scientists (including medical practitioners) in almost all discoveries and inventions, to strengthen Soviet patriotism. This was a requirement dictated by the 
era and by Joseph Stalin himself, but it must be admitted that, in the lifetime of P. Stradinš̌, this department never became dominant in the museum, there was a reasonable balance between scientists from different nations and countries, although the contribution of the West and Latvian pre-war medical traditions were "silenced"'" [3: 56-57].

The Museum of Medical History was also perceived in two ways - some people saw it as an eccentricity of a famous professor, a waste of power, while others took the museum seriously, because it was known that even J. Stalin paid attention to the history of science and used it to fight cosmopolitanism [4:9].

Professor of Arts J. R. Tillbergs commented on Professor P. Stradiņš artistic principles in the creation of the museum: "Professor wanted to show medicine on a very large scale in his museum - from the ancient world through the Middle Ages to Soviet medicine. At first, certain stages of development were greatly represented by photographs in the exhibition, but Professor wanted to have everything in a more solid and fundamental form - in portraits and genre paintings. ... I had to paint portraits of many famous medical men for the Museum's exhibition. ... It was always necessary to keep in mind what frame would fit this or that painting. Professor had a whole collection of painting frames at his disposal - he knew all of Riga's antique dealers and frame masters, who always informed him as soon as an antique frame had appeared" [5: 198-199].

The political situation in the Soviet Union changed after Stalin's death. On 3 September 1957, the Council of Ministers of the Latvian SSR decided to organise a special state museum based on the medical history collection collected by Professor Pauls Stradiņš [6: 47]. A four-storey building at Leona Paegles (now Antonijas) Street 1 was provided for the museum. However, Prof. P. Stradinš was not destined to see the opening of the museum to the public on its new premises in Riga in July 1961. The name of its founder, Professor Pauls Stradiņ̌š, was given to the museum on 18 August 1958, after his death [7: 78].

\section{THE MUSEUM BUILDING}

The museum's eclectic-style building on Antonijas Street 1 in Riga was built in 1875 according to the design of architect Heinrich Karl Scheel (1829-1909) [8] as a luxurious family mansion. Scheel has designed more than 40 buildings in Riga. After the founding of the Republic of Latvia and until World War II, the owner of the house Rodrigo Wilhelm Elsen leased it to the embassies of Belgium (the first two floors) and Lithuania (the upper floor) [9]. 
The Soviet government nationalised the building, and the Central Committee of the Young Communist League was located in it immediately after World War II. In 1957, the building was handed over to the museum. Within a few years it was adapted to the needs of a public museum, and, since 1961, the permanent exhibition of the Museum has been on show on its three floors as well as on the basement floor. The total area of the museum premises is $2490 \mathrm{~m}^{2}$ [10]. An enclosed patio garden and the wide fenced green strip along Antonijas Street and Kalpaka Boulevard are adjacent to the museum building. The museum's patio garden is the only garden open to the public on Riga boulevards arcs. (Fig. 3).

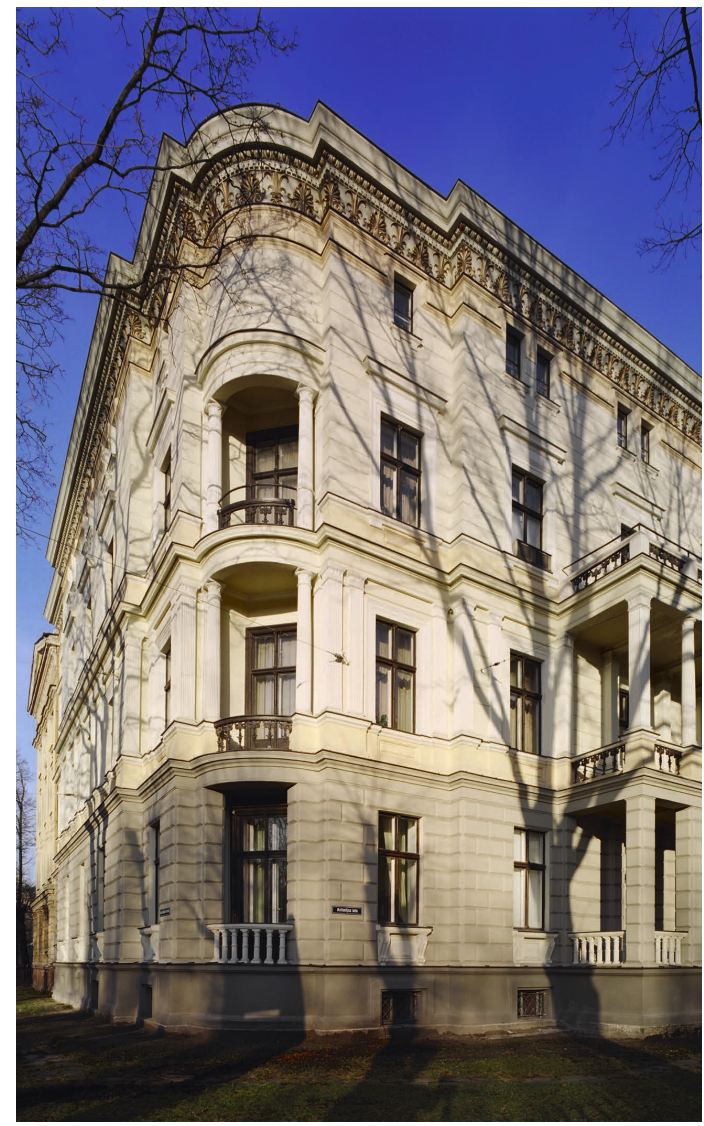

Figure 3. Main building of the Pauls Stradinš Museum of the History of Medicine in Rĩga. (Pauls Stradiňš Museum of the History of Medicine).

\section{WORK OF THE MUSEUM IN 1961-2020}

To what extent did the museum follow the ideas of its founder Prof. Pauls Stradiňs in its further development? In its 60 years of existence, the museum has grown, improved, developed, changed and strengthened its position among other museums in Latvia as well as found its niche in the family of museums of history of medical sciences of the world. According to some indicators, such as the exhibition area, the number of employees, the number of exhibits related to the development of medicine in Russia and especially in the USSR, it has the leading position among the medical museums in the world. 
However, just as before the granting of the status of a state museum, the museum has retained the conceptual directions of its founder and served as a training base in the history of medicine for all students of Latvian higher medical schools.

The geopolitical position of Latvia, including the museum, between the West and the East as well as the peculiarities of the Baltic cultures have always determined the content of the main themes, keeping the development of the world medicine in mind, although this was not easy to do, especially during the Soviet period. In the 1960s-1980s, the state ideology dictated that half of the display should be dedicated to the so-called "achievements" of Soviet medicine. At that time, it even determined the distribution of exhibits not by generally accepted periodisation, but by socio-economic formations. Therefore, the museum had departments of medicine of the primitive-communal society, under slavery and feudalism, departments and exhibitions of capitalist and communist medicine. Under this name, flattering to the existing power, much evidence of time was collected and stored, which, in other circumstances, would have been destroyed as unacceptable and even harmful to the Soviet power. It required great heroism and risk from museum managers and research staff to hide truly valuable historical exhibits.

With Gorbachev's perestroika, the situation began to change. This allowed to replace the exhibits, which until that time had been on show and proved the leading role of Lenin and the Communist Party in Soviet public health care, with exhibits that, under encrypted names and different legends, were hidden for years in the museum's repository and interest in which had been growing in proportion to the nation's desire for independence. It was at this time that the museum exhibition began to change.

\section{THE MUSEUM'S COLLECTIONS}

Initially, researchers at the museum lacked experience in labelling its very specific collection of materials related to the history of medicine. After the death of the museum's founder, hundreds of objects collected by him and his collaborators were left without any description at all as to when they were found, from whom they had been obtained and how.

New methods and tools which had never been used in the region had to be adopted so that the collection could be deciphered and preserved. Sometimes specialists had to take their own decisions while investigating these issues, and the examination of the stored collection of the museum revealed earlier mistakes and the need to reverse earlier decisions. 
The annual increment of stored items is approximately 1500 units (Fig. 4). In the early 1990s, Pauls Stradiņš Museum of the History of Medicine was the first museum in Latvia to launch electronic record-keeping, but the project eventually proved unsuccessful because of the constant updating of software at the global level. The absence of appropriate templates which museums could use in common was another problem. This was a good reason to re-evaluate the system and methods once again. Currently, the museum has joined the state system for digitizing the exhibits of museums in Latvia.

What, then, were the basic ways to enrich the museum's collection? Following the traditions of professor Stradinšs, the museum cooperated with outstanding artists and asked them to create artworks based on specific subject matter. Examples of this include wooden sculptures of Hippocrates and Albert Schweitzer, which are the work of the sculptor J. Vasiljevs. There are portraits of many famous physicians, large genre pictures, wall paintings and a fresco which shows the most prominent physicians throughout history. Artists were invited to design interiors and exhibition rooms, too.

The Stradiñš Museum has taken over several collections, particularly since the collapse of the USSR. These are the collections which had no proper owners, which could not be exhibited, and which were not researched. Since 1991, many Soviet-era hospitals, outpatient departments, pharmacies and laboratories have been shut down or have begun to replace Soviet-era equipment with modern Western equipment.

Another example is the most interesting and valuable collection of Ilya Mechnikov (1845-1916), who established the theory related to phagocytosis and was awarded the Nobel Prize in 1908. The history of the collection is unusual as it was cared for by several institutions in the Soviet Union. The Pauls Stradiñš museum has held the collection since 1975, and it was first displayed to the public in 1982 [11: 405] (Fig. 5).

The anatomy branch of the museum was created when it was discovered that a collection of anatomical specimens of scientific and historical value in Rīga Medical Institute (now Rīga Stradiņš University) might be lost because the collection was not properly recorded, and students were using it for their own educational purposes [12:59-60]. A very similar story is related to the collection of plaster casts of diseases from the leprosarium in Talsi. As the last leprosarium in the Baltic countries, it was closed as late as at the very beginning of the 21st century.

The Pauls Stradiņš Museum keeps many of its exhibits on display - not just individual objects, but entire collections that have been donated by the heirs of former historians of medicine, professors and famous physicians such as 


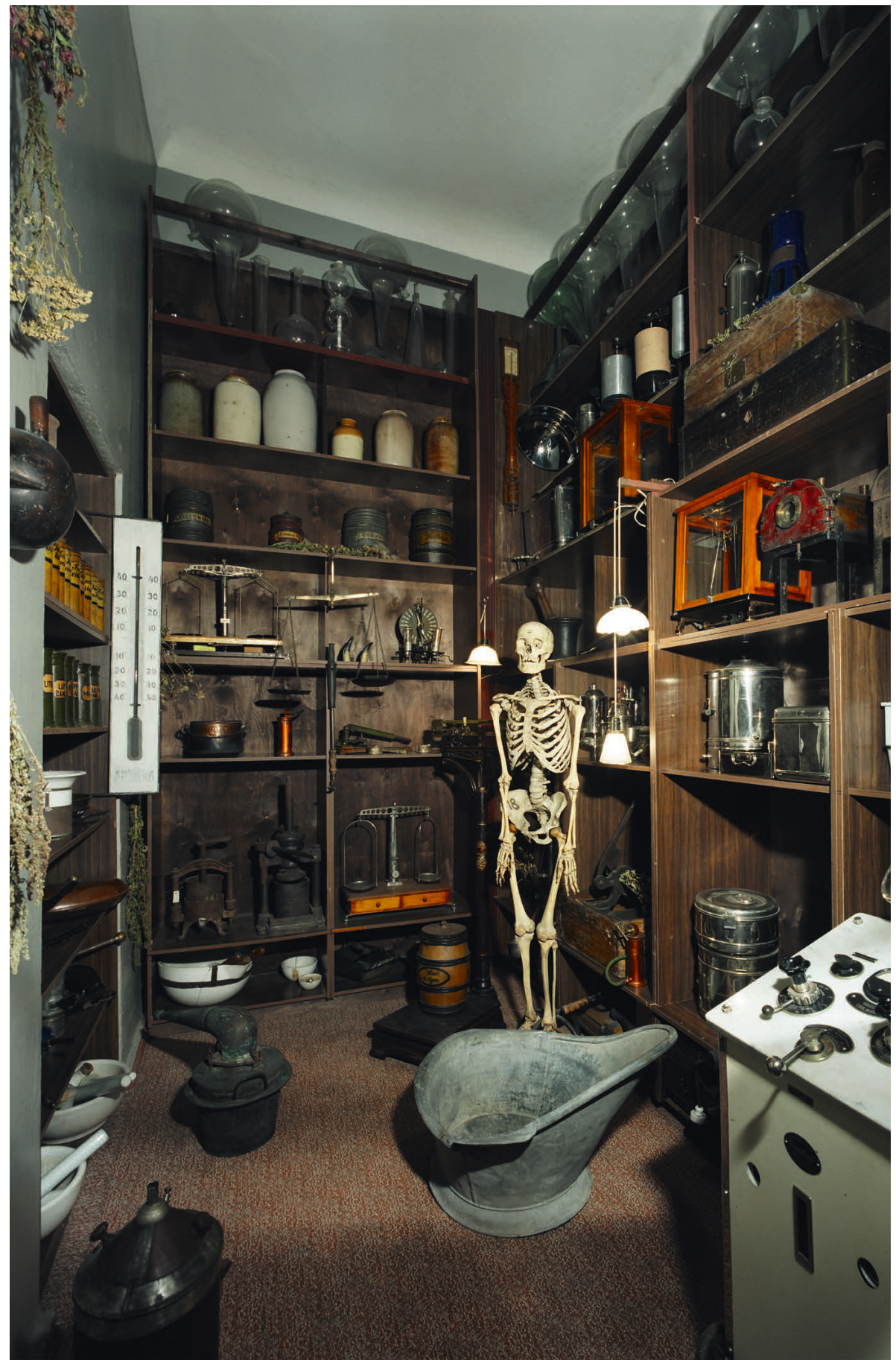

Figure 4. Open storage of the museum. (Pauls Stradinšs Museum of the History of Medicine). 


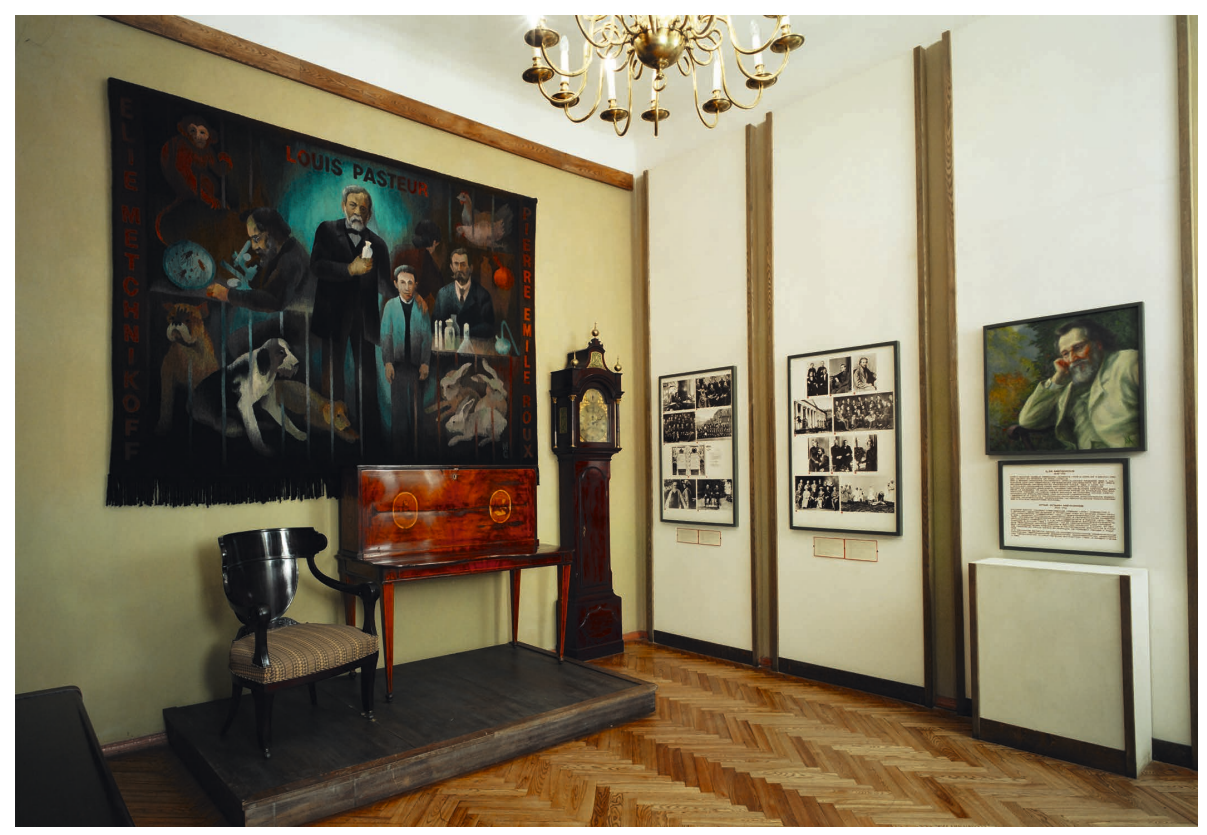

Figure 5. Fragments from the permanent exhibition dedicated to microbiologist llya Mechnikov. (Pauls Stradinš̌ Museum of the History of Medicine).

Maizìte, Ternovsky, Multanovsky, Vigdorchik, Müller-Dietz, etc. The museum has managed to amass a unique collection of old medical texts, many of them in Latin. That is because some of the older libraries in the Soviet Union refused to accept such books, arguing that there was no readership for them.

Purposeful updating of collections involves expeditions which are organised by the employees of the museum. For example, there is a collection which focuses on the Shaman medicine of the people of Russia's Far North. In the past, exhibits were gathered from different parts of the former Soviet Union and from old medical institutions that were modernised. In recent decades, private collectors and online auctions have come to the fore, along with traditional places for purchase of exhibits, such as antique shops, art galleries, etc. A dedicated committee of experts evaluates each potential purchase.

The collections of the museum are divided into several departments:

- The Department of Photographic, Audio and Visual Objects (82412 units)

- The Department of Manuscripts and Documents (49573 units) - original manuscripts, templates, correspondence, certificates, maps, etc.

- The Department of Rare Books (17834 units) 
- The Department of Medical Objects (48416 units) - medical instruments and equipment, anatomical, archaeological and palaeopathological specimens, equipment from apothecaries, hygiene objects, textiles, furniture, etc.

- The Department of Artworks (15433 units) - sculptures, paintings, engravings, book illustrations, tapestries, models, medals, etc. [13]

For a long time, the museum had two restoration workshops of its own for the restoration of exhibits made of paper and metal. Very unique or specific restoration work was carried out in other museums on the basis of separate contracts. The biggest achievement on the eve of the 50th anniversary of the museum was the opening of a new state-of-the-art repository.

\section{THE EXHIBITION}

Until now, the exhibition has continued to preserve in the traditional Soviet museum decorum of the second half of the 20th century, justifying this with the concept of the museum's creator, which was supposed to clearly reflect the development of all medicine from ancient times to the present day, with an emphasis on the Baltic region and the Russian state, represented by unique and authentic exhibits. The mapping of the specificity of the Baltic region did not ignore the main episodes in the development of world medicine. On the contrary, the emphasis was on the interaction of cultures and the borrowing of medical knowledge. For this reason, copies of well-known sources were created, scenes of medical events staged with papier-mâchier dolls. As a result of subsequent research in various fields of medicine and collaboration with artists, their own original artworks appeared. These are new portraits, sculptures or genre paintings that often differ from the traditional ones found in textbooks on the history of medicine.

Therefore, in the exhibition of ethno-primitive medicine, stories are presented mainly by dioramas which represent the characteristics of healing in ancient times. Dioramas are complemented by glass showcases with findings of palaeopathological bones, various objects of worship and unconventional methods of treatment, which have remained almost unchanged to this day and are still used by some tribes on several continents. For example, special collections of shamanic medicine were collected during the expedition in the late 1980s in the Far North of the Soviet Union.

Medieval medicine is represented by one large complex. Against the background of a theatrical performance of a medieval city, it was possible to 
successfully show all elements of medicine of this period: hygiene, epidemics, hospitals, a pharmacy, diagnostics, differentiation in medicine, etc.

Judging by the reviews, it is mainly this part of the exhibition that attracts most visitors of all ages, although this spectacular part of the exhibition is gradually changing. For example, the history of pharmacy of this period was given a new look by combining colourful genre paintings acquired by the museum from the Latvian artist Miervaldis Polis, old books and symbols of the pharmaceutical fraternity with the reconstruction of a medieval pharmacy. Similar changes have taken place in the part of the exhibition representing the medieval hospital. New items are combined with an artistic diorama, mannequins dressed in authentic clothes, furniture and other attributes that mimic the reality of treatment in a medieval hospital as much as possible (Fig. 6). In fact, the most difficult task is to balance and position exhibits so that they would follow a unified concept of the museum, since the display created in the late fifties of the last century contrasts sharply with the trends and options of present-day exhibition design.

The story about the history of modern medicine is revealed on examples of various medical topics, for example, the development of surgery after the introduction of anaesthesia, the rules of asepsis and antiseptics, pathology,

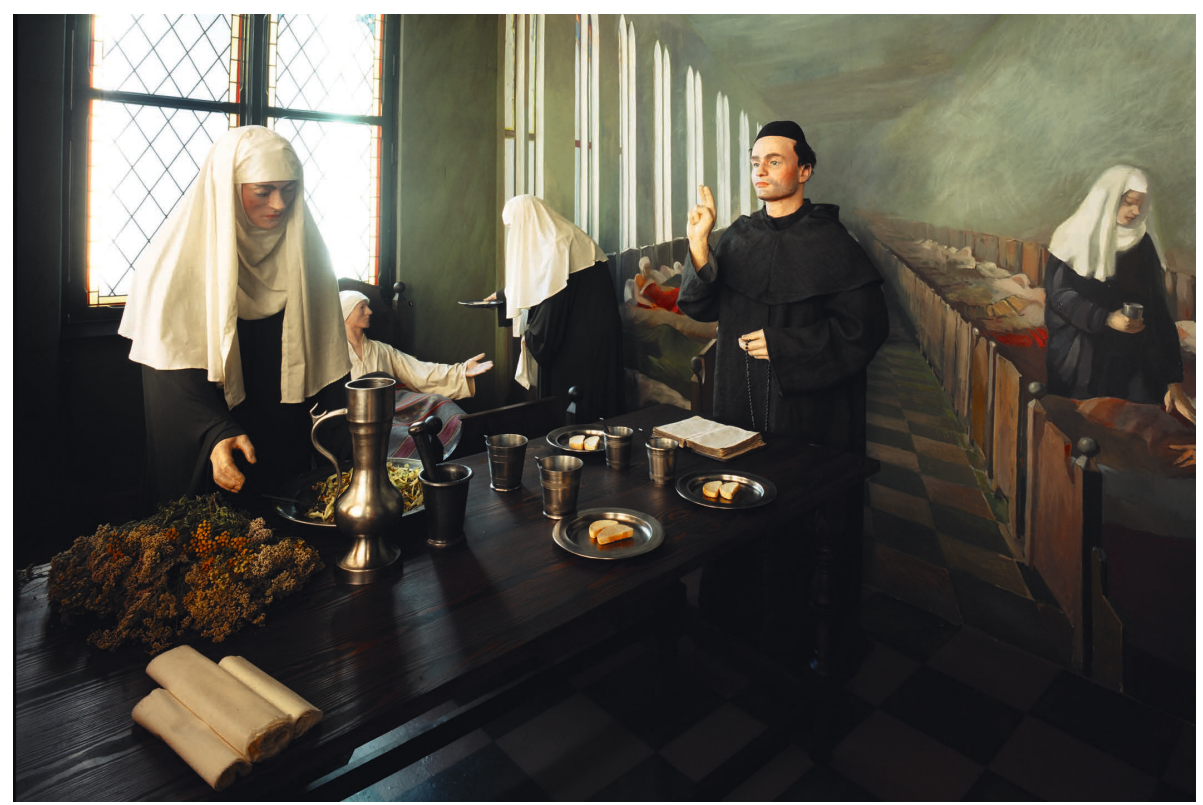

Figure 6. Fragments from the present permanent exhibition: Medieval hospital and town. (Pauls Stradinšs Museum of the History of Medicine). 


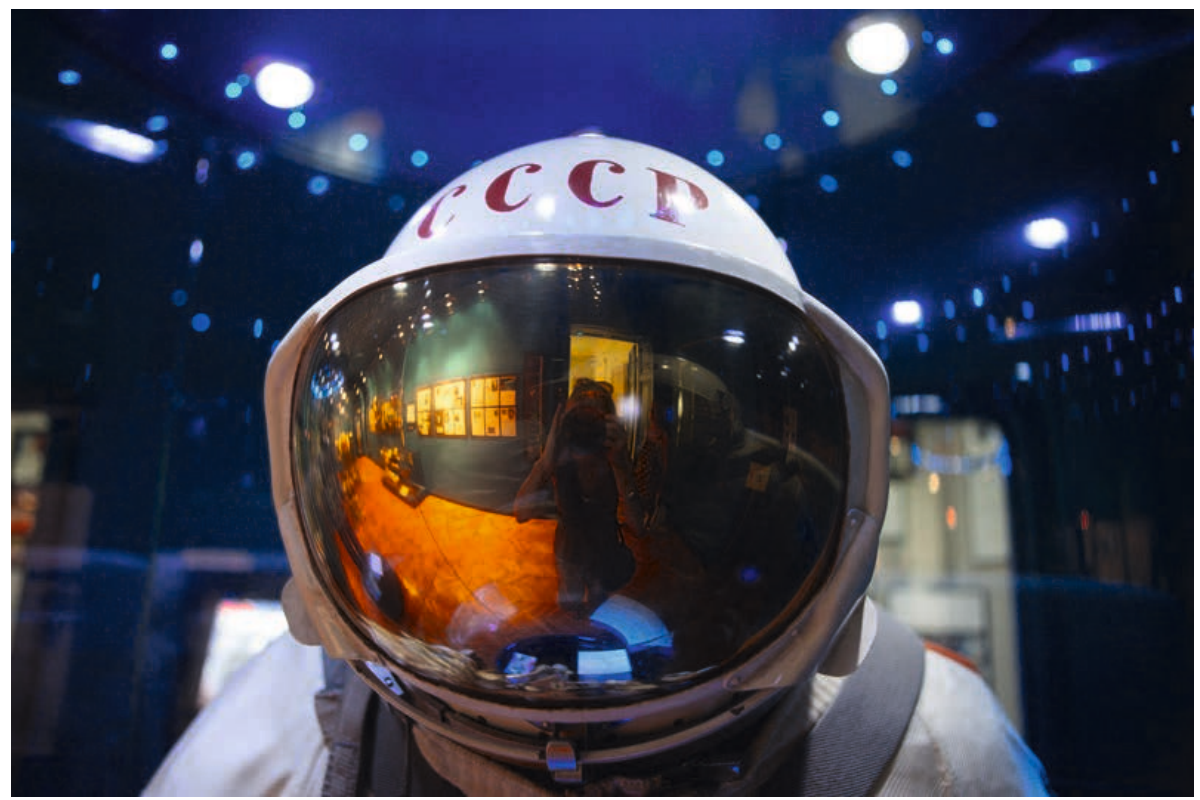

Figure 7. Fragments from the present permanent exhibition: Medicine in space. (Pauls Stradinš Museum of the History of Medicine).

physiology, microbiology, psychiatry, etc. Thematically selected objects are books, documents, collections of medical instruments or equipment, portraits or genre scenes and even sculptures; they give an idea of a specific branch of medicine, for example, collections of stethoscopes, impact hammers and pleximeters, X-ray medical devices, rehabilitation equipment for recovering the health of patients, and others. The memorial collection of Ilya Mechnikov is exhibited in its own interior where original items are displayed along with samples of period furniture and, in addition, a large tapestry with images of famous microbiologists.

Medicine of the 20th century is mainly represented by the development of medicine in Latvia, reflected in several halls of the permanent exhibition. Among them there was an exhibition about the art of healing in Riga during 800 years since the foundation of the city. It was originally created as a Riga jubilee exhibition in 2001 but remained on display for almost the next 20 years. The memorial collection of the founder of the museum, Professor Pauls Stradinšs, expanded significantly when the museum widely celebrated its 100th anniversary in 1996 [14: 230-233]. Since the end of the last century, an exhibition on the development of medicine in Latvia between the two world wars has also existed with minimal changes. 
The final hall of the permanent exhibition is dedicated to space medicine. There are many unique items collected from various institutions and cosmonauts of the former Soviet Union. This exhibition has become a historical and unique story about Soviet space medicine. There was a lot of discussion among the museum staff - should we continue to preserve this exhibition or put it in storage? In 2010, it was decided to preserve and thoroughly renovate it.

Now it is obvious that there is no display about the development of health care in Soviet Latvia and in the whole USSR. Previously, such exhibits occupied $1 / 3$ of the exhibition area of the museum. Now, three decades afterwards and having unique material on this topic in the museum's collections, it is possible to arrange such an exhibition, and it would be interesting for both those who witnessed that time and the younger generation. The interest of foreign colleagues and researchers in the so-called Soviet collection is obvious. This is the only such complete collection in the world. Actually, it is a treasure that distinguishes Stradinšs museum from other medical history museums in the world.

Changes are necessary and possible in other halls of the museum, since the exhibits presented in the permanent exhibition make up only $1 / 20$ of the museum's collections in storage. This is a good prerequisite for updating the exhibition and synchronising it with the interests, needs and expectations of the modern museum visitor.

\section{RESEARCH}

The study of the history of medicine has always been a tradition in Latvia. With the creation of the museum, this research was concentrated in the museum. This made Stradiņ̌̌ Museum different from other museums in Latvia until the beginning of this century.

The research spirit of the Museum of the History of Medicine was outlined in Pauls Stradinšs lifetime. Namely, in 1958, the collection of articles Из истории медицины Vol. I edited by P. Stradiņš was published, which also included the majority of articles from the Museum of the History of Medicine [15: 278-279]. It was the only publication on the history of medicine in the whole USSR. In 1992 its 20th volume appeared under the new title Acta Medico-Historica Rigensia and with an international editorial board. Contrary to the previous volumes, the present edition contains articles by foreign authors and not only in Latvian but also in English. From 1997, the Institute of the History of Medicine of Rīga Stradiňš University joined the editorial board. Now 
Acta Medico-Historica Rigensia is published once a year. It is a peer-reviewed academic open-access journal dedicated to research on the history of medicine and life sciences and medical museology in Latvia and the Baltic states. Until now, 32 volumes have been issued [16].

At the very end P. Stradinş life, another of his plans finally came true - to hold a conference on the history of natural sciences and medicine in the Baltic states. It took place in Rìga in 1958 [17: 309]. This meeting started the tradition of conferences on the history of Baltic sciences. The 30th Baltic Conference on the History of Science is scheduled for 2021 in Finland.

The traditional research themes on the history of medicine in the Baltics were led by Professor Jānis Stradiņš (1933-2019), son of the museum founder and patron of the museum. The museum has always closely cooperated with the Institute of the History of Medicine of the Riga Stradiņš University, which made it possible to combine efforts in the development of certain research themes, including medical museology and to conduct educational work on the basis of the museum.

In the past, the unique character of the museum and the accumulated experience made it the centre of methodology for medical museums and collections in the USSR. During the first two decades after 1991, scientific relations with Russia were almost broken due to many political barriers. Now they have partially recovered at a new level of development and with new players. On the contrary, relations with the Western medical museums have developed rapidly. Since 1986, the museum has been a member of the European Association of Museums of the History of Medical Sciences, and it has had a representative on the board of the Association. As a result, the XXIII Congress of the Association was held at the museum in Riga in 2006. For many of the guests, it was the first opportunity to see Pauls Stradiñ̌ Museum of the History of Medicine in Riga, although they had heard quite a lot about it before.

For decades, the former museum director Karlis Eriks Arons (1933-2005) cultivated an exemplary scientific partnership with colleagues from Germany. This was embodied in joint conferences and exhibitions, publishing of books and booklets, an exchange program for doctoral students, etc. It is no coincidence that the first foreign scientist who received the Pauls Stradiņš Prize in 1990 , established by the museum for research in the history of medicine, was Professor Heinz Müller Dietz (1923-1998) from the Free University of Berlin, and in 2005 Professor Christa Habrich (1940-2013) - director of the German Museum of Medical History in Ingolstadt [18: 116]. 
The scientific library of the museum and the collection of rare books (more than 40,000 volumes) are available not only to the museum staff but also to specialists, students and anyone interested in the history of medicine.

The conglomerate of the aforementioned research work of the museum together with its educational work meets the criteria of an institute of the history of medicine of a Western type. And such an institute was created under the umbrella of Riga Stradinšs University in 1991. The institute developed extensive research themes commissioned by the museum. This does not mean that the museum has refused to do research, but it helped to concentrate on the specific functions of the museum and to limit research to objects in the museum as well as on medical museology.

The museum also accommodates the Latvian Society for the History of Medicine. In the mid-1950s, Pauls Stradiňš became a member of the International Society of the History of Medicine (ISHM) and intended to invite medical historians from around the world to open the museum [19:30]. His death in 1958 prevented this from happening. In tough competition, the strong lobby of the museum and Rìga Stradinš University in ISHM won the right to organise the ISHM Centennial Congress in Riga in 2020. The 47th ISHM Centennial Congress was postponed to 23-27 August 2021 due to the Covid19 pandemic [20].

\section{THE FUTURE OF THE MUSEUM}

The global pandemic experience has brought stress and conflict into public opinion on issues of health. The museum's ability to address it is limited. Similarly to other museums around the world, Pauls Stradiņš Museum of the History of Medicine is closed for visitors and with no reopening date forecasted yet when writing this article in the spring of 2021. The museum's earlier communication strategies - implemented through exhibitions and educational programmes - need new approaches to knowledge production and distribution. Because of the pandemic, there is an unprecedentedly high public demand for answers the museum is neither legitimate nor informed enough to give. There is also little clarity on how a medical history museum can be socially engaged, proactive and relevant when 'history' is suddenly reduced to predictive analytics of the latest 24-hour statistical data of the pandemic. With conspiracy theories all over the social media eroding the authority of expertise, the museum is forced to inspect its own competencies, social status and cogency of argumentation. 
The history of medicine shows that it is not just the preconceptions of illnesses or their treatments that change over time. The understanding of health and what it means to be healthy changes as well. The attitudes to one's own body or the bodies of others, the care for the physical wellbeing of oneself and the people around us are shaped by the cultural traditions, socially accepted norms and personal habits. A museum that examines and reflects on these two processes of change is also a part of them.

The emergency situation caused by Covid-19 has prompted to replace the museum's 60th anniversary celebrations with "an institutional health-check" and critical rumination on what is meant by 'health' The museum has taken the challenge of the historical moment to redefine itself through a year-long public research programme focused on the institution's grounding history, the decades of ideological compromises and the unclear provenance issues of its vast and cross-disciplinary collection. The future potential of the museum's traditional methodologies of arrangement of exhibitions and audience engagement will also be explored and refined.

Parts of the museum's permanent exhibition have remained unchanged for more than half a century. These are unique pieces of historical evidence of museology which should be preserved, but they lack a contemporary interpretation. Hence, what is missing is critical counterbalance to the overoptimistic expectations from sciences back in 1961, the year when the museum was opened, and Yuri Gagarin made the first space flight in human history. Over the years, the museum has lost its vanguard punch in areas that were once its most spectacular specialities, including space medicine. Back on planet Earth, the museum is facing heretofore unconsidered ethical and sociopolitical questions. How to preserve the stability of life-supporting ecosystems under the effects of climate change? What does life mean for natural sciences in the age of gene medicine? Or what is the definition of empathy when global economic inequality creates divergence in healthcare standards?

It is crucial for the museum's redefinition plans that in dealing with medicine as a science of nature and technology, the perspective of its social history and the cross-disciplinary ties with anthropology, environmental humanities and life sciences are equally recognised. The 60th anniversary programme is therefore organised as a processual research laboratory and provides a wide exchange of ideas between the museum staff and residence researchers, public stakeholders and general audience on the museum's collection, library resources and loft archives. The prism of different outlooks and life experiences, diverse professional approaches and academic or artistic tools will be essential to the 
museum's future work on planning new exhibitions, educational programmes, research and collecting. The residency programme was launched by Katrīna Neiburga and Jānis Noviks, active present-day Latvian artists with good knowledge of creative research methods and media technologies. By the help of artistic interventions and pop-up collection displays in the permanent exhibition, they have highlighted the less noticeable or even missing parts in the museum's narratives of history - the absence of the patient's point of view, the high-stakes risks of self-experiments in science, the political dimension of history writing of medicine in post-Soviet Europe.

To the museum as to any other organism, maintaining health in the conditions of an ever-changing environment means a constant ability to recover and adapt. And each instance of recovery and adaptation tends to transform the understanding of what health actually is.

\section{REFERENCES}

1. Stradyn' Ja. P. (1960). Stanovlenie Muzeja istorii mediciny professora P. I. Stradynja. In: Iz istorii mediciny, III. Riga. 139-153 (in Russian). Страдынь Я. П. (1960). Становление Музея истории медицины профессора П. И. Страдыня. Из истории медицины, III. Рига. 139-153.

2. Stradinšs J. (1961). Dienu ritums un noskaņas. In: Profesors Pauls Stradiņš dzīvē un darbā. Rīga. 223-235 (in Latvian).

3. Stradiņš J. (2007). Paula Stradiņa Medicīnas vēstures muzeja tapšana un izveidošanās. Acta Medico-Historica Rigensia, VIII. Rīga. 31-116 (in Latvian).

4. Jaroševskij M. G. (1991). Stalinizm i sud'by sovetskoj nauki. In: Repressirovannaja nauka. Leningrad. 6-33 (in Russian). Ярошевский М. Г. Сталинизм и судьбы советской науки. In: Репрессированная наука. Ленинград. 6-33.

5. Tillbergs J. (1961). Draugos ar mākslu. In: Profesors Pauls Stradiņš dzīvē un darbā. Rīga. 197-201 (in Latvian).

6. State Archive of Latvia, Stock 270, Series 2, Item 2845.

7. State Archive of Latvia, Stock 270, Series 2, Item 2999.

8. Jūgendstila arhitekti. Heinrihs Šèls. (2021). https://jugendstils.riga.lv// JugendstilsRiga/ssels [Accessed 5 April 2021].

9. Pauls Stradinš Medicine History Museum. History of the buildings. (2021). https://mvm.lv/en/history-of-the-buildings [Accessed 5 April 2021].

10. Latvian cultural data portal. Pauls Stradiņš Museum for History of Medicine. Statistics. (2021). https://kulturasdati.lv/lv/muzeji/paula-stradina-medicinasvestures-muzejs [Accessed 5 April 2021]

11. Salaks J. (2014). The Ilya Mechnikov collection in Riga. In: Chemical Immunology and Allergy, 100. Basel: Karger. 405-408. 
12. Lībiete I., Grāvere R. (2018). Rīgas Stradiṇa universitātes anatomiskās kolekcijas zudušo vēsturi meklējot. In: Acta Medico-Historica Rigensia, XI. Riga. 53-91 (in Latvian). https://doi.org/10.25143/amhr.2018.XI.02

13. Report on the number of materials in the Pauls Stradiņš Museum of the History of Medicine storage as of January 1, 2020. Report for internal use. (2020).

14. Salaks J. (2009). Emergence and development of Paul Stradiņš Museum. In: Medicina nei Secoli, 21,1. 215-243.

15. Iz istorii mediciny, I. (1957). AN Latv. SSR. Riga. 1-279 (in Russian). Из истории медицины, I. АН Латв. ССР. Рига. 1-279.

16. Acta Medico-historica Rigensia. About the journal. (2021). https://www.rsu.lv/ en/AMHR [Accessed 5 April 2021].

17. Pervoe mežrespublikanskoe soveštšanie po probleme izučenija istorii estestvennykh nauk i mediciny Pribaltiki. (1959). Iz istorii mediciny, II. Riga. 309-313 (in Russian). Первое межреспубликанское совещание по проблеме изучения истории естественных наук и медицины Прибалтики. (1959). Из истории медицины, II. Рига. 309-313.

18. Salaks J. (2015). International Cooperation of the Pauls Stradiňš Museum of the History of Medicine. In: Acta Baltica Historiae et Philosophiae Scientiarum, 3, 2. Tallinn. 115-119. https://doi.org/10.11590/abhps.2015.2.07

19. Sondervorst F. A. Paul Stradin. (1959). In: Bulletin et Mémoires de la Société Internationale d'Histoire de la Médicine, 1, 4. 30.

20. The 47th Congress of the International Society of the History of Medicine webpage. (2021). https://ishm2020.rsu.lv/ [Accessed 5 April 2021].

\section{Address for correspondence:}

Juris Salaks

Institute of the History of Medicine

Rīga Stradiņš University

Kronvalda bulvāris 9, Rīga, LV-1010, Latvia

E-mail: juris.salaks@rsu.lv 